トピックス

\title{
アミノ酸の非対称性の起源: RNAワールドの観点から
}

田村浩二 東京理科大学基礎工学部生物工学科 / 東京理科大学総合研究機構 / 科学技術振興機構さきがけ

\section{1. はじめに}

天然のタンパク質は，特殊な例外を除いて，L-アミ ノ酸のみから構成されている。リボザイムの発見は, RNA が最初の生命として，情報の担い手であると同 時に酵素として機能し得た可能性を示す「RNAワー ルド」仮説 ${ }^{1)}$ の提唱につながったが，本稿では，RNA ワールドの立場から，アミノ酸のホモキラリティーの 起源を考えてみたい.

\section{RNA のキラル選択的アミノアシル化}

RNA が初期生命として機能していたとき，アミノ 酸のホモキラリティーを決定する場面は, RNA とア ミノ酸とがはじめて出会らステップであっただろう。 現在の生物系において，それは「tRNAのアミノアシ ル化」反応に相当する。 これは，一般的に，アミノア シル tRNA 合成酵素（aaRS）によって活性化されたア ミノ酸（アミノアシル AMP）を対応する tRNAに結 合させる 2 段階反応であり，一旦，アミノアシル AMP が生成されれば， tRNAへの転移はエネルギー的 にダウンヒル反応である。一方，tRNA は L 字型の立 体構造を有しているが，「ミニヘリックス」とよばれ る $\mathrm{L}$ 字の片方の腕に相当する部分は，aaRSの基質に なりらる場合が多く，アンチコドン部分に先立って確 立された，原始 tRNA としての形態を保存していると 考えられる ${ }^{2)}$ (図 1 参照).

アミノアシル AMP，抽び，オリゴヌクレオチド は，前生物学的環境でも生成されることが実験的に示 されているので，アミノ酸が（アミノアシル AMP と 同一の）アミノアシルリン酸結合を介してオリゴヌク レオチドにつながった形の分子（アミノアシルーリン 酸ーオリゴヌクレオチド) が，前生物学的に作られて いた可能性は高い. RNA ワールドでのアミノアシル 化の起源に迫るために, アミノアシルーリン酸ーオリゴ ヌクレオチドを用いて，タンパク質なしの状態で，ミ
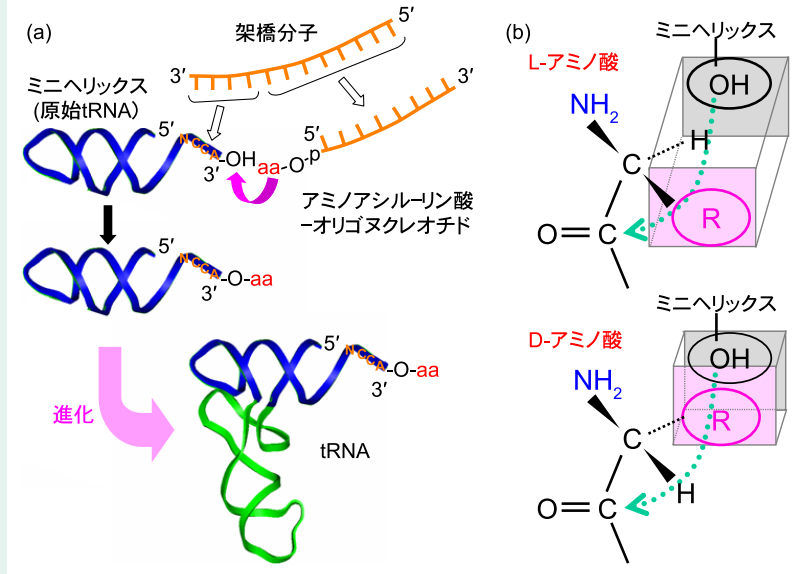

図 1

RNA ミニヘリックスのキラル選択的アミノアシル化.（a）アミノ アシルーリン酸ーオリゴヌクレオチドを用いたアミノアシル化と tRNA への進化. (b) キラル選択性を生み出すメカニズムの概略 (電子付録参照).（電子ジャーナルではカラー）

ニヘリックスのアミノアシル化を試みた.

tRNA と同様に, ミニヘリックスにも存在する 1 本 鎖の CCA 配列とアミノアシルーリン酸-オリゴヌクレ オチドの双方の配列に相補的な配列を有する架橋分子 を用い，アミノ酸をオリゴヌクレオチドのリン酸基か らミニヘリックスの $3^{\prime}$-末端のアデノシンの $\mathrm{OH}$ 基へ と移動させた。 反応部位は $3^{\prime}-\mathrm{OH}$ の部分に限られた。 このような制約は，アミノ酸のキラル選択性にも影響 を与え, L-アミノ酸が D-アミノ酸よりも4 倍程度優 位にアミノアシル化された ${ }^{3)}$.

RNAのリボースはD-リボースで構成されており， 現在の地球上の生物界は「L-アミノ酸, D-リボース」 といら特徵的なホモキラリティーをもった存在であ る。この組合せの重要性は，すべての RNAを $\mathrm{L}$ 型の リボースで作製し，同様の実験を行った結果，D-ア ミノ酸のほうが優位にミニヘリックスにアミノアシル 化されたことからも確かめられた ${ }^{3)}$.

アミノアシル化反応は, ミニヘリックスの $3^{\prime}-\mathrm{O}$ が

Origin of Asymmetry of Amino Acids: Relationship to the RNA World Koji TAMURA

Department of Biological Science and Technology, and Research Institute for Science and Technology, Tokyo University of Science / PRESTO, Japan Science and Technology Agency 
アミノアシルリン酸結合上のカルボニル炭素を求核攻 撃することによって始まる。求核試薬 $(\mathrm{Nu})$ による カルボニル炭素の攻撃は, $\mathrm{Nu}-\mathrm{C}=\mathrm{O}$ のなす角が約 $105^{\circ}$ になるような制約のもとで起こり，その角度は Bürgi-Dunitz angle として知られている. 結論からいう と, D-アミノ酸の側鎖はミニへリックスに対して近 接して位置し，この立体障害によって，D-アミノ酸 の移動が阻害されている（図 1 および電子付録参 照 $)^{4)}$. 詳細は省くが，アミノ酸の最隣接部位のヌク レオチドに非ワトソンークリック型塩基対を導入する ことで，この謎が解けた。 さらに，リボースのパッカ リングの違いにも依存した微妙なキラル選択性が関与 していることも明らかになった5゙.

\section{L-アミノ酸の起源}

さまざまな実験事実から，生命進化のある時点で， RNA ワールドが存在したのは間違いないと思われる. この立場に立つと, アミノアシル化の過程を通して, L-アミノ酸が選ばれ，ホモキラルなタンパク質合成系 を生み出したといらストーリーを描くことができる.

しかし，これらの話は，D-リボースから構成され る RNA ワールドの存在を前提としている，RNAワー ルドにおけるD-リボースの起源に関しては，RNA ワールドの成立過程について考察する必要がある. RNA ワールドは, RNAの短いオリゴマーの重合に よってできたと考兄られるが，すべての組合せを含む 任意のエナンチオマーで構成されるオリゴマーを出発 物質として，それらの重合で得られる長いRNAは， 必ずホモキラル（すべてDかすべて L ）になること が実験的に示されている6 ${ }^{6}$. そして，最終的に，D-ラ イブラリと L-ライブラリに含まれる RNA の配列は同 一ではなくなる。この状況で，生命の進化にかかわる

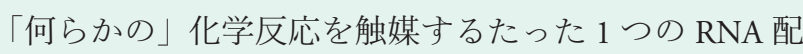
列がたまたま D-ライブラリに現れ，もはや L-ライブ ラリには存在できない，といら状況が生まれてくる. RNA ワールドにおいて，D型の糖が選ばれた理由は， おそらくそのようなものであっただろう》。

\section{4. おわりに}

本稿では, RNAのアミノアシル化の過程がアミノ 酸のホモキラリティーを決めた可能性があるといら立 場から話を進めたが，これが真実である確証はない．
生命誕生の頃の原始地球の環境が，現在より高温であ ることが明らかになってきており，RNAワールドが 存在したにしても，ピュアなRNAワールドではなく， さまざまな他の物質を含んだ RNAワールドだったの かもしれない。また，本稿で示したキラル選択性は， 最初にL-アミノ酸からなるペプチドが生成し，それ が D-リボースから構成される RNAを選択したといら 可能性を否定しない，強調すべきことは，RNAが確 かにアミノ酸のキラル選択性を識別する構造的要素を 有しており，それが実験的に検証できたという点であ ろら。 今後, 生命の起源のような問題にも，実証的な アプローチを取っていくことが，Scienceを真に成熟 した段階に押し上げると信じたい。

\section{謝 辞}

本稿の内容は, The Scripps Research Institute の Paul Schimmel 教授との共同研究の成果を含んでおりま た，科学技術振興機構・さきがけ（RNA と生体機能） から資金助成を受けた。ここに感謝の意を表す。

文 献

1) Gilbert, W. (1986) Nature 319, 618.

2) Schimmel, P., Ribas de Pouplana, L. (1995) Cell 81, 983-986.

3) Tamura, K., Schimmel, P. (2004) Science 305, 1253.

4) Tamura, K., Schimmel, P. R. (2006) Proc. Natl. Acad. Sci. USA 103 13750-13752.

5) Tamura, K. (2008) Biosystems 92, 91-98.

6) Tamura, K. (2009) J. Biosci. 34, 991-994.

7) Tamura, K. (2010) J. Cosmol. 5, 883-889.

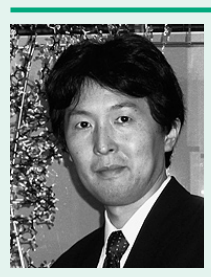

田村浩二（たむら こうじ）

東京理科大学基礎工学部生物工学科・准教授 1989 年東京大学理学部物理学科卒業. 94 年同大 学院理学系研究科物理学専攻博士課程修了. 博士 (理学). 同年理化学研究所基礎科学特別研究員. 95 年同研究員. 99 年米国 The Scripps Research Institute 客員研究員. 2001 年同研究員. 03 年同 上級研究員. 06 年東京理科大学基礎工学部助教 授を経て, 07 年より現職. 08 年より科学技術振 興機構・さきがけ研究者（RNA と生体機能）を, 10 年より東京理科大学総合研究機構のメンバー を兼任.

研究内容:生体物質化学, 生物物理学 連絡先: ‘ 278-8510 千葉県野田市山崎 2641

E-mail: koji@rs.noda.tus.ac.jp URL: http://www.rs.noda.tus.ac.jp/ biost/OPFU/ TAMU/kojitamuralab.html 